\title{
A SMALL INTRUDER: \\ A MEDIEVAL MARBLE WINGED LION FROM RAVELLO
}

\author{
Maria Vittoria Fontana - Sapienza University of Rome
}

\begin{abstract}
An image of a $12^{\text {th }}$ century marble winged lion was provocatively included among the slides accompanying a lecture by the author at a recent conference at the American Academy in Rome to illustrate Umberto Scerrato's work on Islamic archaeology and art history in Italy. The lion, in fact, was never published by Scerrato, but it and a winged bull, both once featuring as ornaments on the "Moresque Fountain" in Ravello (originally from a medieval building most likely from Ravello itself), are the subject of this brief article. They are of undeniable Islamic taste.
\end{abstract}

Keywords: Ravello (Campania); Italy; marble sculptures; Norman period; Islamic contacts

\section{INTRODUCTION}

When I was recently invited to talk about Umberto Scerrato and his contribution to the study of Islamic archaeology and art history in Italy at the International Conference on Islamic Art and Architecture in Italy: Between Tradition and Innovation (held by the American Academy in Rome, 17-18 May 2018), I decided to include, among the images taken from his publications, an image of a small "intruder". It is a medieval marble winged lion which Umberto Scerrato and I spoke about but he never mentioned in his writings, even in his important chapter on Islamic art in Italy in the volume Gli Arabi in Italia, first published in $1979 .^{1}$

\section{THE WINGED LION AND THE WINGED BULL FROM RAVELLO (figs. 1-4)}

This marble sculpture featuring a winged lion was once reused (see below), together with another marble sculpture depicting a winged bull (probably both from the $12^{\text {th }}$ century), as ornaments on a fountain (the so-called "Moresque Fountain", fig. 1) in the middle of the homonym square in the southern Italian town of Ravello, from where they were removed on $13^{\text {th }}$ September $1975^{2}$ and replaced by copies (figs. 9-10) at the end of the 1970s. ${ }^{3}$

The original marbles, certainly from a medieval building - most likely from Ravello itself -, were for a long time considered part of the ciborium of Ravello cathedral. ${ }^{4}$

I invited people attending the Conference to discover it together (a sort of treasure hunt), at the end of my speech.

2 Cf. White 1987, 179. The original lion was also reproduced by Escher in 1932 (wood engraving, 23,2 × 21,3 cm; Locher 1992, fig. 214).

3 The copies of the two marble statues were produced in lava stone by an artist from Catania (Sicily; cf. http://www.comune.ravello.sa.it/2018/fontana-moresca/, last accessed 08/06/2018).

4 This ciborium, which was commissioned in 1279 by Matteo Rufolo and produced by Matteo di Narnia, was demolished in 1773 at the behest of bishop Michele Tafuri due to its poor static conditions (Mansi 1887, 77; cf. also White 1987, 176). From Francesco Pansa onwards (see the long description from Pansa's 1865 manuscript reported in White 1987, 176, 178, 180) it was believed that the lion and the bull belonged to this ciborium and crowned one of the corners formed by the four elements of the architrave (see among the others: Mansi 1887, 74-76; Bertaux 1978², 766; Toesca 1965, 898, n. 77; Bottari 1955, 236, pl. XLIX, fig. 4 (the lion); Guglielmi Fedeli 1972, 33, figs. 29-31). Vega de Martini (1984) was among the first to suggest that the 
The features of both the lion and the bull recall other more famous marbles used as supports: marble, or less commonly stone, stylophore animals were very widespread in southern Italian churches during the $11^{\text {th }}-13^{\text {th }}$ centuries, and their shapes and renderings revealed specific contacts with the Islamic world. ${ }^{5}$ Scerrato's essay from 1979 represents a precious guide containing many comparisons.

\subsection{The winged lion (figs. 2, 4)}

The lion is standing with its head bent slightly to the right, its legs strong, its wings closed, and its tail folded along its back. It is distinguished by its mane which resembles a wig lowered onto its forehead. This latter detail is paralleled in a marble lion acting as the support of a stoup in Siponto cathedral (Apulia), but originally supporting a chair which is now lost (ca. 1050; fig. 5). A very similar arrangement of the mane on the forehead is also found on a rock crystal lionhead, most likely from South Italy (ca. 1200), preserved at the Museum für Islamische Kunst in Berlin, ${ }^{6}$ and on a marble lion that is part of an Apulian fragmentary capital (first half of the $12^{\text {th }}$ century) in the Pinacoteca Civica of Bari. ${ }^{7}$

The elongated oval-shaped flat nose is instead similar to those of the porphyry lions of the sculptured tomb of Friedrich II in Palermo cathedral ${ }^{8}$ as well as those of the lions depicted on the coronation mantle of Roger II of Sicily (fig. 6): ${ }^{9}$ as a matter of fact this winged lion is quite different from the Ravello cathedral specimens. ${ }^{10}$

\subsection{The winged bull (fig. 3)}

The bull is also standing, its head bent slightly to the left, as if its and the lion's gazes were converging towards a central point or diverging from the latter, depending on their location. Its legs, wings and tail show the same features as those of the lion. The "realistic" rendering of its oblong eyes, wide nostrils, and, overall, wrinkled bovine skin - the latter achieved through deep, parallel lines carved into the marble surface - is of some interest. Indeed, an immediate comparison with the latter could be suggested: it is the as or more wrinkled skin that distinguishes the renowned pair of marble elephants supporting the throne of bishop Urso (1078-1089) in Canosa cathedral (Apulia), the work of Romualdus (fig. 8).

two statues could not have crowned one of the corners of the ciborium. In fact she observed that the flat structure on their backs can only suggest that they were supporting and not crowning elements.

5 Stylophore marble lions from churches in the Campania hinterland can also show more specific Western features (see, for example, Pace 2007, figs. 257-260).

Inv. no. I. 4650; Shalem 1999, fig. 5.

Scerrato 1979, fig. 320

Originally made for Roger II around 1145-1154; Déer 1959, figs. 18, 25-27, 30-32.

548H/1133-34 CE, Vienna, Kunsthistorisches Museum, Kaiserliche Schatzkammer, inv. no. XIII 14. The latter is not so different from the fountain lion protome painted in the panel illustrating two musicians in front of a fountain on the wooden ceiling of the Cappella Palatina in Palermo (fig. 7), as well as the many lions depicted on the same ceiling (Brenk 2010, Atlante / Atlas, II, figs. 530, 568-569, 588, 605, 607, 647, 666, 685, 717, 720-721, 733, 762, 764, 776, 786, 807-808, 826, 839, 859, 891-892, 899, 907, 978, 1150-1151).

$10 \quad$ See Guglielmi Fedeli 1972. 
The bent heads of both the lion and the bull could actually suggest that they were placed opposite each other, and their wings confirm that they are two of the four Evangelists symbols, belonging to a unique lost monument on which they acted as supporting elements. ${ }^{11}$

\section{CONCLUSIONS}

The circulation of Islamic models in southern Italy undoubtedly occurred in the lead up to the Norman period, as several Greek illustrated manuscripts especially produced in southern Italy between the $9^{\text {th }}$ and $11^{\text {th }}$ centuries testify. ${ }^{12}$ In the Norman period Islamic metalwork and textiles also provided many visual sources for southern Italian marble workers; thus Islamic metalwork may have acted as a model for hundreds of marble statues $\left(11^{\text {th }}-12^{\text {th }}\right.$ century) in the form of animals (both quadrupeds and birds) abounding in the portals, capitals and furnishings of Apulian churches in particular, and Islamic textiles may well have supplied prototypes, for example, for the square and rectangular marble reliefs $\left(10^{\text {th }}-11^{\text {th }}\right.$ century) from the old dome of Sorrento now kept in the Museo Correale in that town and in the Museo Barracco in Rome. ${ }^{13}$

The lion and the bull of Ravello are probably not the best proof of the skill of marble workers from Campania, in fact their manufacture is rather coarse and certainly less refined than that of Apulian and other specimens from Campania, ${ }^{14}$ but they are, in my opinion, very impressive and represent important evidence of the craftsmanship of marble sculptures from the middle Tyrrhenian coast, also indebted to the Islamic repertoire.

This is perhaps the reason - together with its peculiar shape - why the inhabitants of Ravello called the "Fontana Moresca" (Moorish Fountain) the pool of water which, at an unspecified time (probably in $18^{\text {th }}$ century), was built and adorned with these medieval marbles. ${ }^{15}$

As mentioned above, after a long discussion on the subject, Scerrato decided not to publish these two marbles, his reticence certainly being due to their uncertain origin.

\section{REFERENCES}

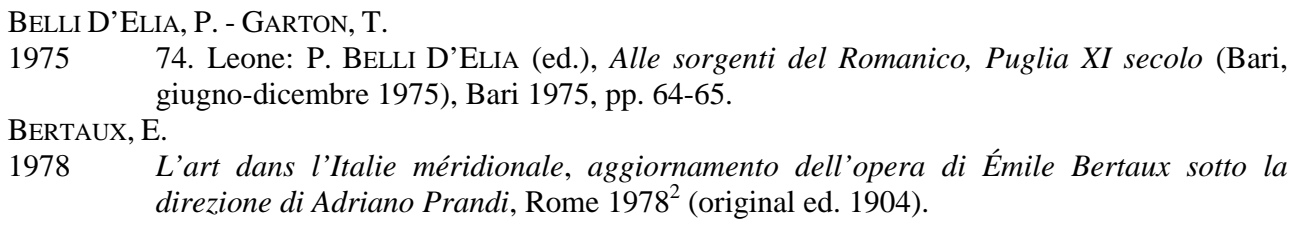

1978 L'art dans l'Italie méridionale, aggiornamento dell'opera di Émile Bertaux sotto la direzione di Adriano Prandi, Rome $1978^{2}$ (original ed. 1904).

11 As mentioned above, many scholars hypothesised that they belonged to a ciborium, but as crowing and not supporting elements of the latter, and specifically of the ciborium of Ravello cathedral (see fn. 4).

12 See Grabar 1972

13 Cf. Scerrato 1979, figs. 393-394, 398-401, and 512, respectively. In turn the illustrations of some Western manuscripts may have also been inspired by numerous Sasanid, Byzantine and Islamic fabrics circulating in both the Mediterranean basin and continental Europe (cf. Fontana 2004).

14 Cf. Volbach 1942.

15 The oldest illustration I found is a lithography by Karl Girardet (a French Swiss painter, d. 1871), published in the journal Le Magasin Pittoresque 10/mars (1842), ill. on p. 81: the fountain was erroneously located in Amalfi. 
BOTTARI, S.

1955 Le sculture di San Marcello Maggiore di Capua: Commentari VI (1955), pp. 235-240.

BRENK, B. (ed.)

2010 La Cappella Palatina a Palermo / The Cappella Palatina in Palermo (Mirabilia Italiæ Charton, M.E. 17), 4 vols., Modena 2010.

1842 Le Magasin Pittoresque, Paris 10 march 1842.

DÉER, J.

1959 The Dynastic Tombs of the Norman Period in Sicily, Cambridge (MA) 1959.

FONTANA, M.V.

2004 A Note on Some Illustrated Pages from Codex Aureus Epternacensis (1030 AD. ca) in the Nuremberg Germanisches Nationalmuseum: A. CARILE (ed.), Convegno Internazionale "La Persia e Bisanzio" (Roma, Accademia Nazionale dei Lincei, 14-18 ottobre 2002) GRABAR, A. (Atti Convegni Lincei 201), Roma 2004, pp. 935-951.

1972 Les manuscrits grecs enluminés de provenance italienne, $I X^{e}-X I^{e}$ siècles (Bibliothèque des Cahiers archéologiques 8), Paris 1972.

Guglielmi FEDELI, C.

1972 Il Duomo di Ravello, Roma 1972.

LOCHER, J.L.

1992 M.C. Escher: His Life and Complete Graphic Work, with a Fully Illustrated Catalogue, MANSI, L.

$1887 \quad$ Ravello sacra-monumentale, Ravello 1887.

MARTINI, V. DE

1984 Aquila: Ravello, il Duomo e il Museo, Salerno 1984, p. 54.

PACE, V.

2007 Aspetti della scultura in Campania: V. Pace, Arte medievale in Italia meridionale, I. SCERRATO, U.

Campania, Napoli 2007, pp. 179-203.

1979 Arte islamica in Italia: F. GABriELI - U. ScERRATo (edd.), Gli Arabi in Italia. Cultura, contatti e tradizioni, Milano 1979, pp. 275-571.

SHALEM, A.

1999 The Rock-Crystal Lionhead in the Badisches Landesmuseum in Karlsruhe: M. BARRUCAND (ed.), L'Égypte fatimide, son art et son histoire, Actes du colloque organisé à Paris les 28, 29 et 30 mai 1998, Paris 1999, pp. 359-366.

TOESCA, P.

1965 Il Medioevo, II, Torino $1965^{2}$ ( $1^{\text {st }}$ ed. 1927).

VOLBACH, W.F.

1942 Oriental Influences in the Animal Sculpture of Campania: The Art Bulletin 24/1 (1942),

WHITE, A. pp. 172-180.

1987 Il ciborio della cattedrale di Ravello: un'ipotesi ricostruttiva e qualche annotazione: AA.VV., Atti della Giornata di Studio per il IX Centenario della fondazione della Diocesi di Ravello (Chiesa della SS. Annunziata, 21 giugno 1986), Ravello 1987, pp. 175-189. 


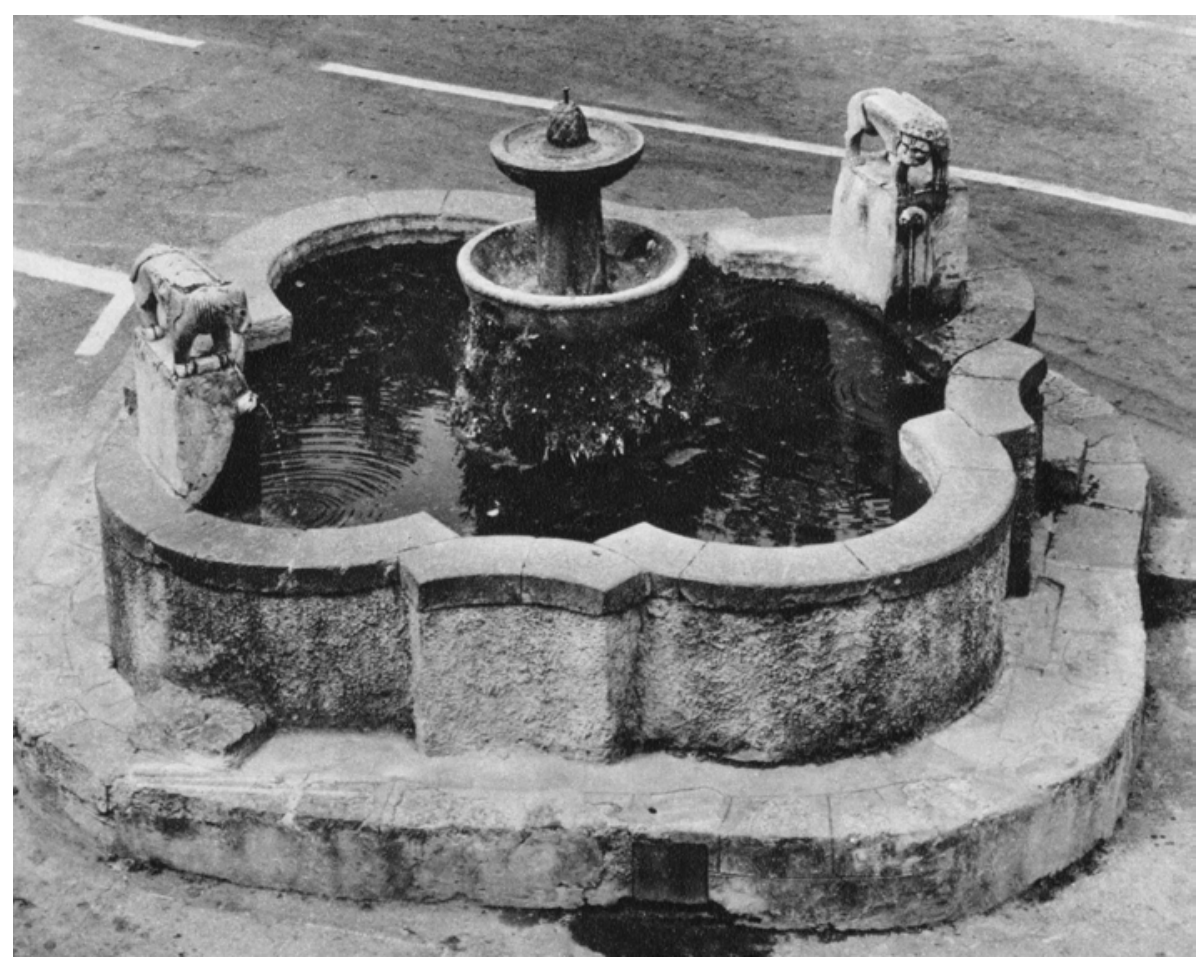

Fig. 1 - Ravello, the "Moresque Fountain" in the homonym square before the marble statues were removed on $13^{\text {th }}$ September 1975 (after Gugliemi Fedeli 1972, fig. 29).
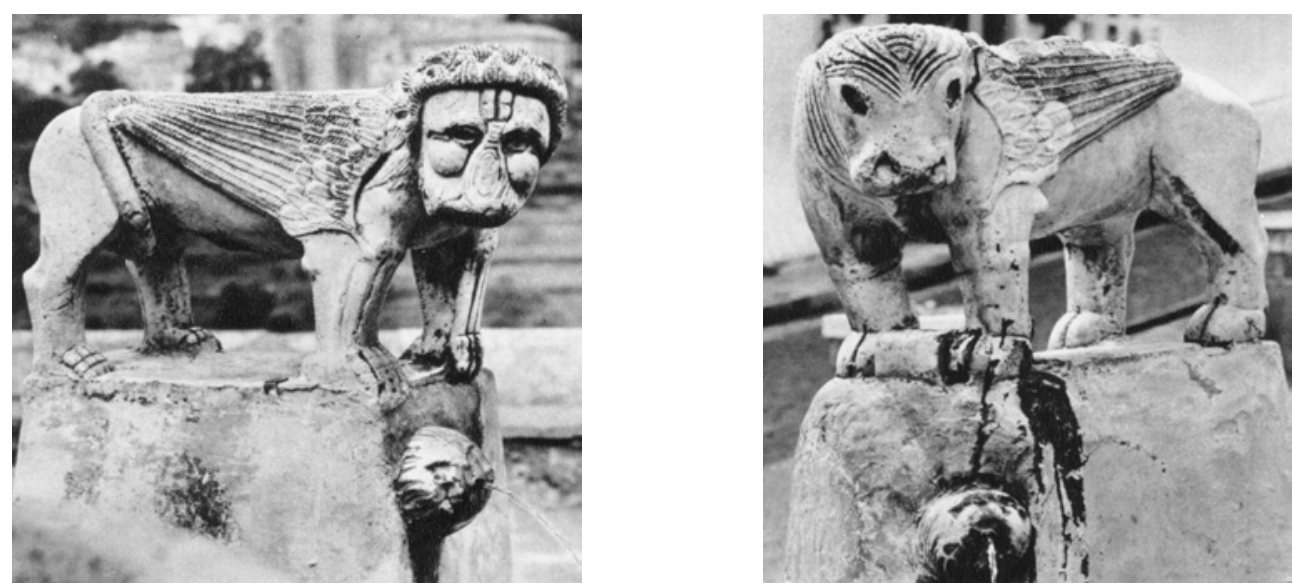

Figs. 2-3 - Ravello, the winged lion (left) and the winged bull (right) (probably $12^{\text {th }}$ century) of the "Moresque Fountain" in the homonym square before the statues were removed on $13^{\text {th }}$ September 1975 (after Gugliemi Fedeli 1972, figs. 30-31). 


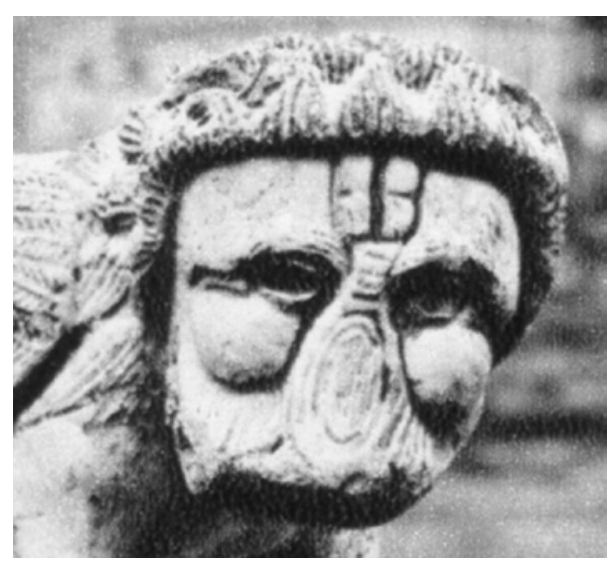

Fig. 4 - Detail of winged lion illustrated in fig. 2.

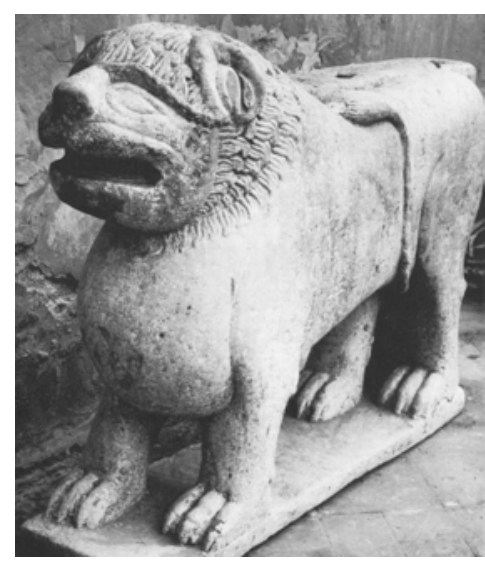

Fig. 5 - Siponto cathedral (Apulia), marble lion originally supporting a chair (ca.1050; after Belli D’Elia - Garton 1975, ill. on p. 65).

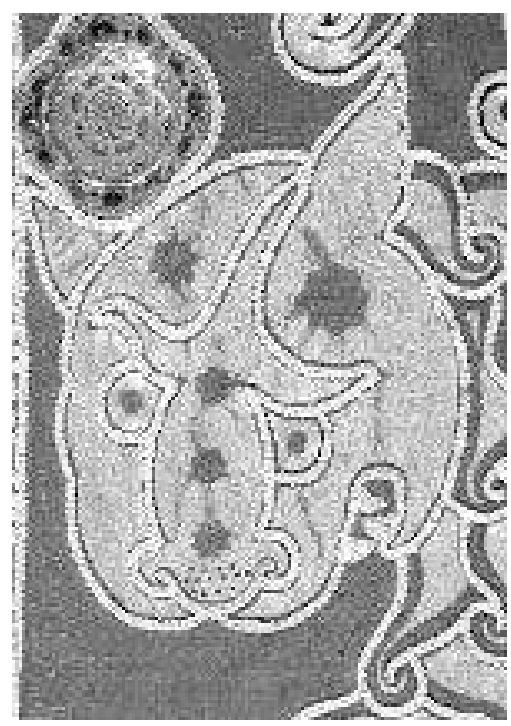

Fig. 6 - Vienna, Kunsthistorisches Museum, Kaiserliche Schatzkammer, Inv. no. XIII 14, mantle of Roger II of Sicily (1133-34), detail (after Scerrato 1979, fig. 149).

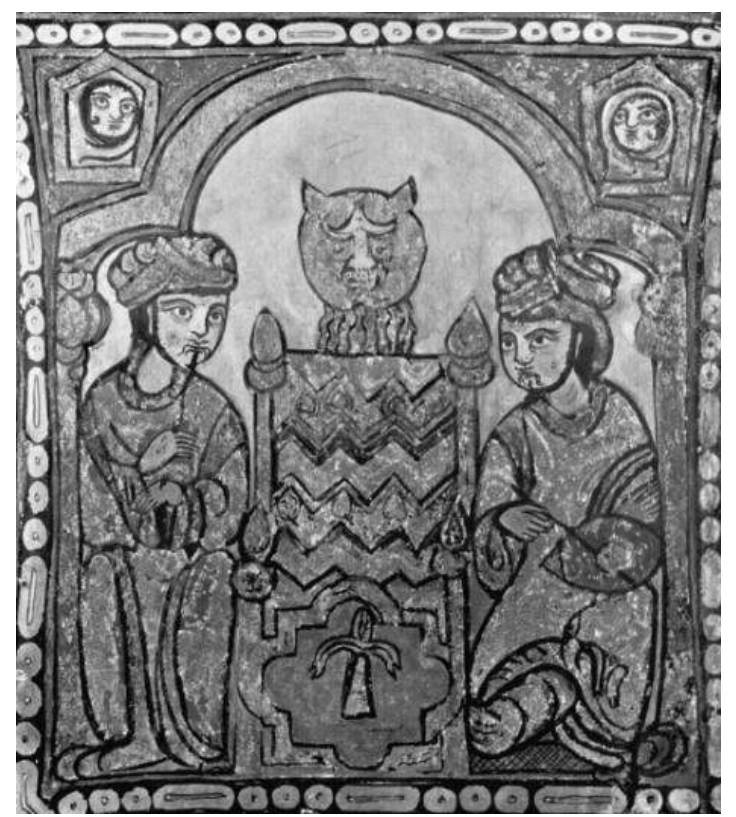

Fig. 7 - Palermo, The Cappella Palatina, panel of the wooden ceiling depicting two musicians in front of a fountain (ca. 1143; after Brenk 2010, Atlante / Atlas, II, fig. 832). 


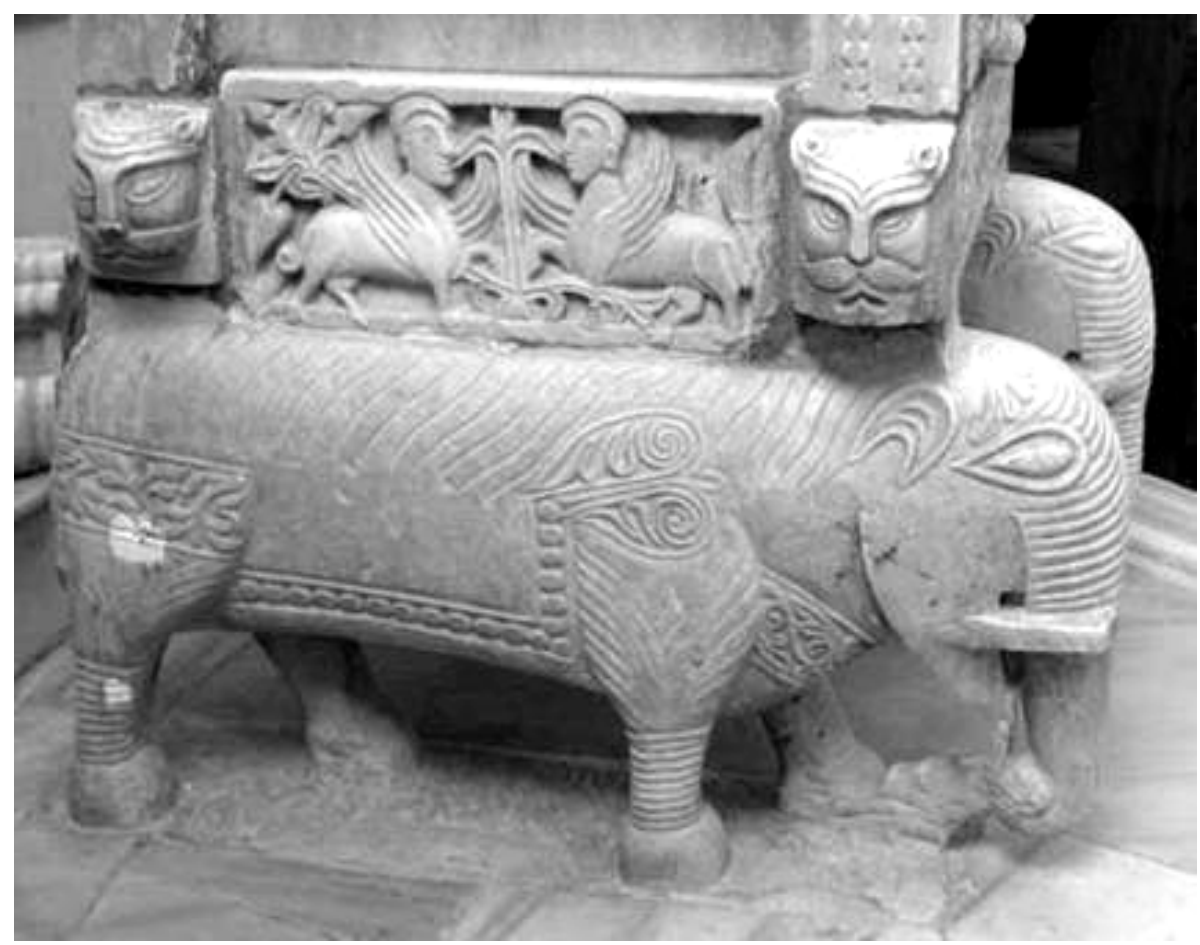

Fig. 8 - Canosa Cathedral (Apulia), a pair of marble elephants supporting the bishop's throne (1078-1089; photo by the author, 1978).
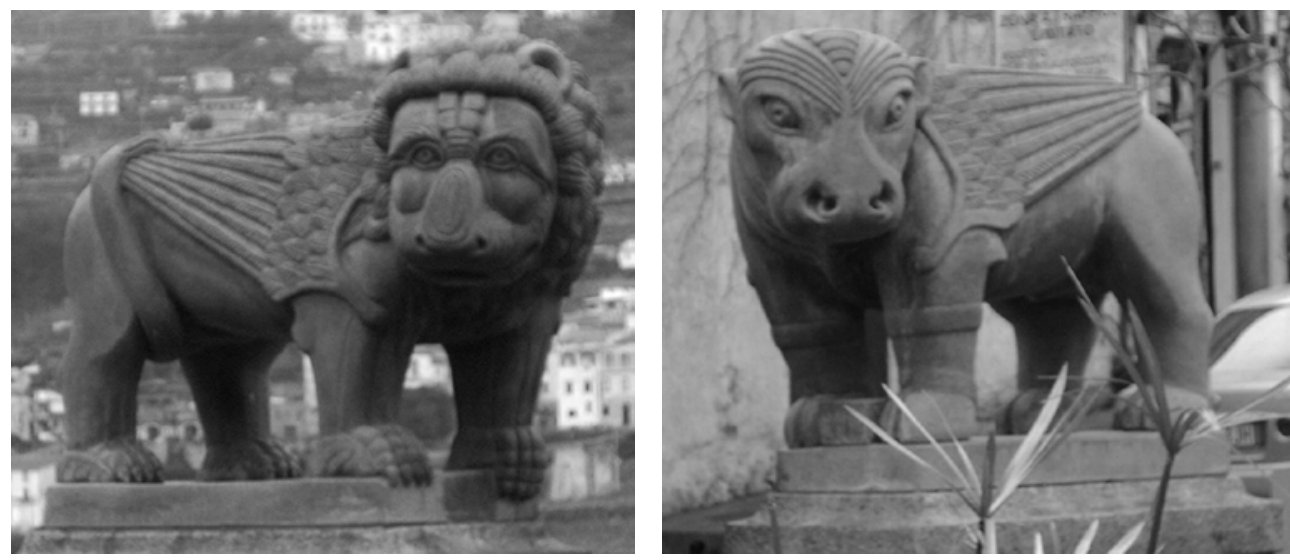

Figs. 9-10 - Ravello, details of the "Moresque Fountain” in the homonym square, lava stone statues by an artist from Catania replacing the original marbles from the second half of the 1970s (photos by the author, 2007). 